\title{
Trophic Relations of Lesser-Spotted Catshark (Scyliorhinus canicula) and Blackmouth Catshark (Galeus melastomus) in the Cantabrian Sea
}

\author{
I. Olaso, F. Velasco, F. Sánchez, A. Serrano, C. Rodríguez-Cabello and O. Cendrero \\ Instituto Español de Oceanografía, P. O. Box 240, 39080 Santander, Spain \\ Olaso, I. F. Velasco, F. Sánchez, A. Serrano, C. Rodríguez-Cabello, and O. Cendrero. 2005. Trophic \\ Relations of Lesser-Spotted Catshark (Scyliorhinus canicula) and Blackmouth Catshark (Galeus \\ melastomus) in the Cantabrian Sea. J. Northw. Atl. Fish. Sci., 35: 481-494. doi:10.2960/J.v35.m494
}

\begin{abstract}
The feeding habits of Scyliorhinus canicula and Galeus melastomus were investigated by analysing the stomach contents from 6036 individuals collected on research surveys in the southern region of the Bay of Biscay during the autumns of 1988-2001. These catshark species are the most abundant scyliorhinids on the Cantabrian shelf. Their depth ranges partly overlap, although they occur in different habitats. Both catshark species are opportunistic scavengers, with their main prey being fish and crustaceans. Diets of the two species overlap; they are most similar in individuals $<30 \mathrm{~cm}$ total length (TL) where euphausiids are important prey, but, for individuals $\geq 30 \mathrm{~cm}$ TL, fish (mainly discarded from trawlers) are important prey. Lesser-spotted catshark are mostly benthic feeders and they feed on a greater diversity of prey than blackmouth catshark, which are more suprabenthic. Resource partitioning between the two species appears to depend on the better vision of the blackmouth catshark, which feeds more in the water column whereas the better developed olfactory sense of the lesser-spotted catshark is an adaptation to benthic feeding. The broad diets of these catshark species and their consumption of fish discarded from trawlers may make them good indicators of fishinginduced change in the Cantabrian Sea ecosystem.
\end{abstract}

Key words: Cantabrian Sea, catshark, food habits, Galeus melastomus, habitat partitioning, Scyliorhinus canicula

\section{Introduction}

Lesser-spotted catshark (Scyliorhinus canicula) and blackmouth catshark (Galeus melastomus) are two abundant elasmobranchs on the continental shelf in the northeast Atlantic (Sánchez et al., 2002). Lesser-spotted catshark are mostly found at depths from 50 to $500 \mathrm{~m}$, especially between 100 and 300 m (Sánchez, 1993), whereas blackmouth catshark are commonly found between 200 and $500 \mathrm{~m}$, but occasionally up to 55 and down to 1400 m (Compagno, 1984; Carrassón et al., 1992). Lesserspotted catshark are more abundant than blackmouth catshark (Sánchez, 1993; Sánchez et al., 2002) and the present study shows for both species that abundance has increased over the past two years. Fisheries data show that landings of lesser-spotted catshark increased from 195 to 259 tons over the past five years (Rodríguez-Cabello et al., 2004a). Similar data are not available for blackmouth catshark. However, because the commercial value of both species is low, landed catches are much lower than the amount discarded (Olaso et al., 1998; Rodríguez-Cabello et al., 2004a).

The lesser-spotted catshark has characteristics which suggest that changes in its abundance and diet may be good indicators of changes occurring in exploited ecosys- tems. Trawling may change the benthos and so modify the abundance of their preferred prey, as well as increase the availability of discards upon which these catshark species feed (Olaso et al., 1998; Rodríguez-Cabello et al., MS 2001; Olaso et al., 2002). Studies of the feeding of blackmouth catshark (Capapé and Zaouali, 1976; Macpherson, 1980; Mattson, 1981) suggest that this species may also be changing its feeding habits due to the supply of energy from fishing discards.

The present study aimed to provide a detailed description of the feeding habits of these two species of catshark in the Cantabrian Sea. In addition, because these predators are capable of expressing characteristics that can indicate the state of the ecosystem they currently occupy, interactions between these predators and their prey are discussed.

\section{Material and Methods}

\section{Fishery and survey data}

Annual trawl surveys were undertaken along the coasts of the southern region of the Bay of Biscay and Galician Atlantic waters during each October (autumn) between 1988 and 2001 (Fig. 1). Using the methodology adopted by Sánchez et al. (2002), trawl hauls followed a 


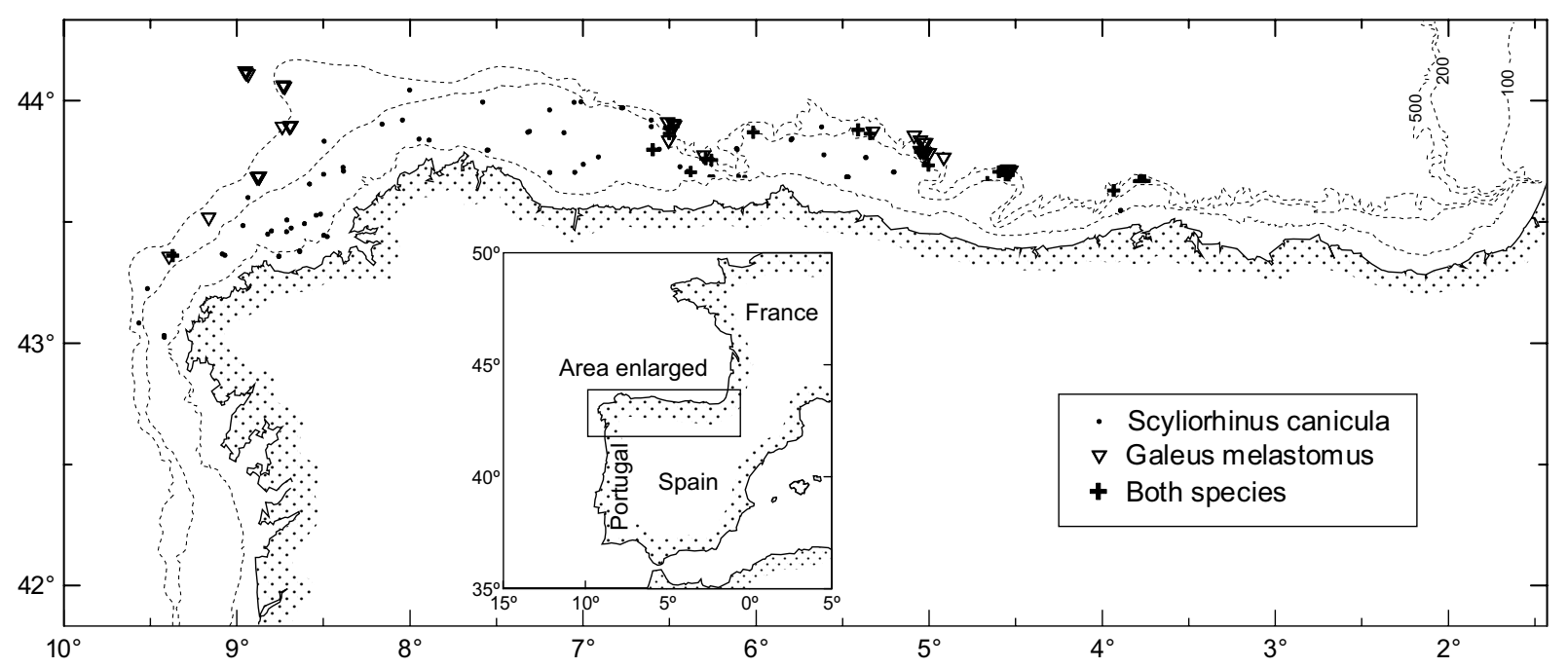

Fig. 1. Location of the study area in the Cantabrian Sea and of hauls containing one or both species of catshark.

stratified random sampling design with otter trawl 44/60 gear of $60 \mathrm{~mm}$ mesh-size and 20-mm mesh-size in the cod-end (Sánchez, 1993). Stratification was by area and depth, with four geographical strata and four depth strata defined by the 100,200 and $500 \mathrm{~m}$ isobaths. The number of days of sampling in each of the 16 strata was proportional to the area of each stratum. During a 13-year period, 763 hauls were made in the study area. As in other studies (Cochran, 1971; Sanchez 1993, Sánchez et al., 2002), an index of abundance was calculated based on the stratified mean catch per 30-min trawl. The stratified mean and variance are given by:

$$
\bar{Y}_{s t}=\frac{1}{A} \sum A_{h} \bar{y}_{h}
$$

and

$$
S_{\bar{Y}_{s t}}^{2}=\frac{1}{A^{2}} \sum \frac{A_{h}^{2} S_{h}^{2}}{n_{h}}
$$

respectively, where $A$ is total surface area, $A_{h}$ is surface area of stratum is mean catch per haul in stratum $h, n_{h}$ is number of hauls in stratum $h$, and is variance in stratum $h$.

Mean catches per $30 \mathrm{~min}$ trawl, grouped within $50 \mathrm{~m}$ depth-intervals, were used to determine the depth distribution of each species. To compare the results from the feeding analyses with those of previous studies, individuals $<30 \mathrm{~cm}$ total length (TL) were classed as 'juveniles' in both species. According to Rodríguez-Cabello et al. (2004b), lesser-spotted catshark of this size are $<2$ years old. Length-at-birth for lesser-spotted catshark is assumed to be 9-11 cm (Ford, 1921; Collenot, 1966; Leloup and Olivereau, 1951; Ellis and Shackley, 1997) and lengthat-maturity is estimated at $54 \mathrm{~cm}$ (Rodríguez-Cabello et al., 1998). Length-at-maturity for blackmouth catshark is estimated at $42 \mathrm{~cm}$ in the Mediterranean Sea; juveniles are reported to be $<34 \mathrm{~cm}$ (Capapé and Zaouali, 1977).

\section{Stomach sampling and analysis}

Stomach contents from 5076 lesser-spotted catshark and 960 blackmouth catshark were collected during bottom trawl surveys. The stomach contents from up to ten individuals for each species were collected from each haul and analysed on-board. Total length (TL), sex, maturity and stomach fullness (containing food, empty or regurgitated) were recorded for each predator specimen. If a fish had food in its mouth or around the gills, or if its stomach was inverted or flaccid, the fish was categorized as having regurgitated food. The total volume of prey items was recorded for each stomach containing food. The volume of each prey group in each stomach was measured using a calibrated instrument consisting of several different-sized half cylinders built into a tray (Olaso, 1990), as used in previous feeding studies of fish (Olaso et al., 1998; Velasco et al., 2001; among others). The relationship between estimated volume and wet weight of the stomach contents was derived from the logarithmic model $\ln$ (wet weight) $=-0.07+0.933 \times \ln$ (volume), where weight is measured in grams and volume in millilitres. Decapod crustaceans and fish were usually identified to species level, but other invertebrates were classified to higher taxonomic levels. The number and digestion stage of each prey item was recorded together 
with the percentage of the total stomach volume occupied by the prey item. In the case of fish prey, the TL of fish or otolith length was recorded.

The diets of fish in three length-classes $(<30,30-49$ and $\geq 50 \mathrm{~cm})$ and three depth strata $(<120,120-299$ and $\geq 300 \mathrm{~m}$ ) were considered separately. The depth strata were based on previous studies of community structure and habitat characteristics (Olaso, 1990; Sánchez, 1993; Sánchez and Serrano, 2003). Adequacy of sampling in each length-class and depth stratum was evaluated by plotting the number of taxa recorded against the number of stomachs sampled for each species of catshark.

\section{Dietary analysis}

The relative importance of individual prey taxa was assessed using percentage volume $(\% V)$. To compare the diets of the two species with different size distributions, a prey specific 'fullness index' $(\% B W)$ was utilised. This is the wet volume of the stomach contents expressed as a percentage of the fish body weight and it was also calculated as a mean for each species by haul using the following correction for stomach contents lost by regurgitation.

$$
\% B W_{i}=\frac{\left[\sum_{h=1}^{H} \frac{F+R}{F \times(F+R+E)} \times \sum_{j=1}^{k} \frac{V_{i j}}{W_{j}}\right]}{H}
$$

and

$$
\% B W=\sum_{i=1}^{x} \% B W_{i}
$$

where $F, R$ and $E$ are the number of stomachs containing food, number of regurgitated stomachs, and number of empty stomachs of the predator species in haul $h$, respectively; $V_{i j}$ is the volume of prey item $i$ in the stomach $j, W_{j}$ the weight of predator $j ; k$ the number of stomachs in haul $h$; $H$ the total number of hauls in which stomachs of the predator species were analysed; and $X$ the total number of different prey categories consumed by the predator. The $\% B W$ index normalises the data of stomach contents in relation to the predator's weight. The percentage of empty stomachs was also recorded. The indices are described by Hyslop (1980).

Differences in trophic diversity between the catshark species were compared by calculating a Shannon-Wiener diversity index, $H^{\prime}$ (Shannon and Weaver, 1949), and evenness, $E$ (Pielou, 1966), for each species where

$$
H^{\prime}=\sum_{i=1}^{s} p_{i} \times \log _{2}\left(p_{i}\right)
$$

and

$$
E=H^{\prime} / H_{\max }=H^{\prime} / \log S
$$

and where $p_{\mathrm{i}}$ is the proportion of the total sample belonging to the $i^{\text {th }}$ species; $S$ the total number of species found in the stomach sampled, and $H_{\max }$ the maximum diversity. Diversity indices were estimated using both the number and volume of prey. To ensure that sample size did not affect the diversity indices for the two species differently, diversity indices of lesser-spotted catshark (the species with the larger stomach sample size) were estimated using a non-parametric bootstrap with 1000 iterations. All iterations had the same number of stomachs available in blackmouth catshark for the same length range. The final diversity value was estimated as the average of the 1000 bootstrap iterations.

To quantify potentially competitive relationships between the catshark species, we obtained the degree of overlap in the specific diets of the two species for different length-classes, using Horn's Overlap Index (Horn, 1966). This index, based on the mean of the volume percentages, which appears to be the most appropriate diet measure (Wallace, 1981), was computed with prey resources defined at the taxonomic level of family. The Horn index ranges from 0 (no overlap) to 1 (complete overlap).

The diets of the two catshark species caught in the same hauls, were compared using the index of relative importance (IRI) (Pinkas et al., 1971). This index combines percentage in number and percentage in volume and frequency of occurrence of each prey item. This index was based on 591 lesser-spotted catshark and 547 blackmouth catshark cohabiting depths between 136 and $382 \mathrm{~m}$ (Fig. 1 and 2).

\section{Results}

\section{Bathymetric distribution of catshark species}

Lesser-spotted catshark inhabited the continental shelf and its maximum abundance occurred between 30 and $200 \mathrm{~m}$ depth. Juveniles inhabited deeper grounds than adults, between 150 and $300 \mathrm{~m}$ (Fig. 2a). However, in some areas adults were also found at greater depth on the slope. Rodríguez-Cabello et al. (1998) suggest that these may be parturition grounds as both gravid females and juveniles were found at depths between 200 and $500 \mathrm{~m}$. Blackmouth catshark were found in deep waters on the continental shelf and in the upper margin of the slope ranging from 150 to $500 \mathrm{~m}$, but mainly between 300 and $500 \mathrm{~m}$ depths. Juveniles inhabited shallower grounds than adults within the depth range $200-350 \mathrm{~m}$ (Fig. 2b). Bottom trawl survey data for the period 1990-2001 indicate that abundance was higher for lesser-spotted catshark than for blackmouth catshark and that the abundance of both species increased during 1999-2001 (Fig. 3). 


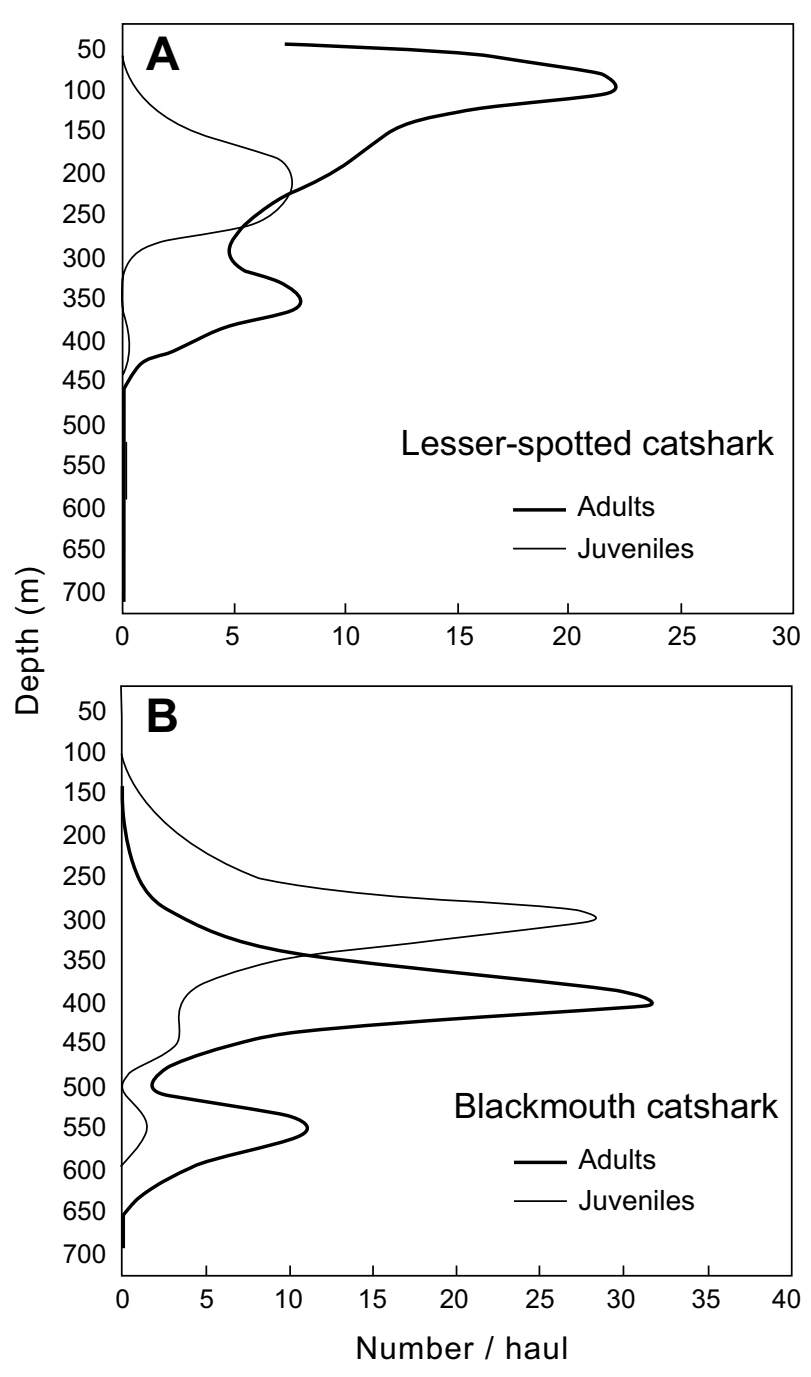

Fig. 2. Bottom trawl survey biomass indices ( $\mathrm{kg} / 30 \mathrm{~min}$ haul) of lesser-spotted catshark and blackmouth catshark.

\section{Diet composition and similarity between species}

Plots of number of prey against number of stomachs analysed were reasonably asymptotic for both species of all length-classes and depth strata, other than blackmouth catshark $\geq 50 \mathrm{~cm}$ TL from $<120$-m depth (Fig. 4). This indicates that for most combinations, sampling was adequate to describe the diets of the catshark species.

Emptiness and regurgitation percentages. Less than $20 \%$ of stomachs were empty in all length-classes of both species (Table 1), but overall a significantly higher percentage of stomachs were empty for blackmouth catshark (16-19\%) than lesser-spotted catshark (11-17\%) $\left(\chi_{(\text {d.f. }=1)}^{2} ; P=0.012\right)$. The percentage of empty stomachs for the two species varied depending on length-class and depth stratum. In lesser-spotted catshark, there were sig- nificant differences between the largest length-class and the two smaller ones $\left(\chi_{\text {(d.f. }=2)}^{2} ; P<0.0001\right)$, but there were no significant differences between depth strata $\left(\chi_{(\text {d.f. }=2)}^{2} ; P\right.$ $=0.174)$. In contrast, for blackmouth catshark there were no significant differences between length-classes $\left(\chi_{(\text {d.f. }=2)}^{2}\right.$; $P=0.454)$, but there were significant differences between the two most well represented depth strata $\left(\chi_{\text {(d.f. }=1)}^{2} ; P=\right.$ 0.036). The occurrence of stomachs from which food had been regurgitated was small for both species.

Diet composition in relation to length. Fish and crustaceans were the main prey of both species (Table 2), but crustaceans were more important for small catshark, and fish were more important prey for the large catshark, particularly in blackmouth catshark. Cephalopods were consumed more by large than small lesser-spotted catshark. Benthic decapods, polychaetes, other invertebrates and benthic fishes were more important in lesser-spotted catshark $\geq 30 \mathrm{~cm}$ TL. However, suprabenthic invertebrates, such as euphausiids, mysids, benthopelagic shrimps and fishes dwelling in the water column were prevalent in the diet of blackmouth catshark $\geq 30 \mathrm{~cm}$ TL (Fig. 5). Catsharks of both species $<30 \mathrm{~cm}$ TL had similar diets, but euphausiids and Micromesistius poutassou were more important prey for black mouthed catshark. Benthopelagic shrimps (Pasiphaea multidentata, P. sivado, Sergestes robustus) were eaten only by blackmouth catshark, whereas shrimps closer to the seabed (Alpheus glaber and Solenocera membranacea) were important prey for lesser-spotted catshark. Pelagic and mesopelagic fish (e.g. Merluccius merluccius, Trachurus trachurus, Scomberesox saurus, and Argyropelecus sp.) were more frequent prey of blackmouth catshark, whereas lesser-spotted catshark fed on a wider variety of benthic and demersal fish (e.g. Arnoglossus laterna, Callionymus maculates, and Trisopterus luscus). Cannibalism occurred in the three length-classes of lesser-spotted catshark ( $0.1 \%$ of the stomach volume) and in adult blackmouth catshark $\geq 50 \mathrm{~cm} \mathrm{TL}(0.5 \%$ of the stomach volume).

A total of 101 prey categories in 10 phyla were recorded for lesser-spotted catshark and 50 prey categories in 7 phyla for blackmouth catshark, although a larger number of stomachs were analysed for lesser-spotted catshark than for blackmouth catshark (Table 2). Decapod crustaceans (mainly natantoids and brachiurids) and fish showed the broadest species diversity in the diet of lesser-spotted catshark (Table 3). Dietary diversity in terms of number of prey was about one third higher in all length-classes of lesser-spotted catshark than in those of blackmouth catshark and 40\% higher for the whole length distribution. In terms of volume, the difference was smaller and only $10 \%$ larger in lesser-spotted catshark for 


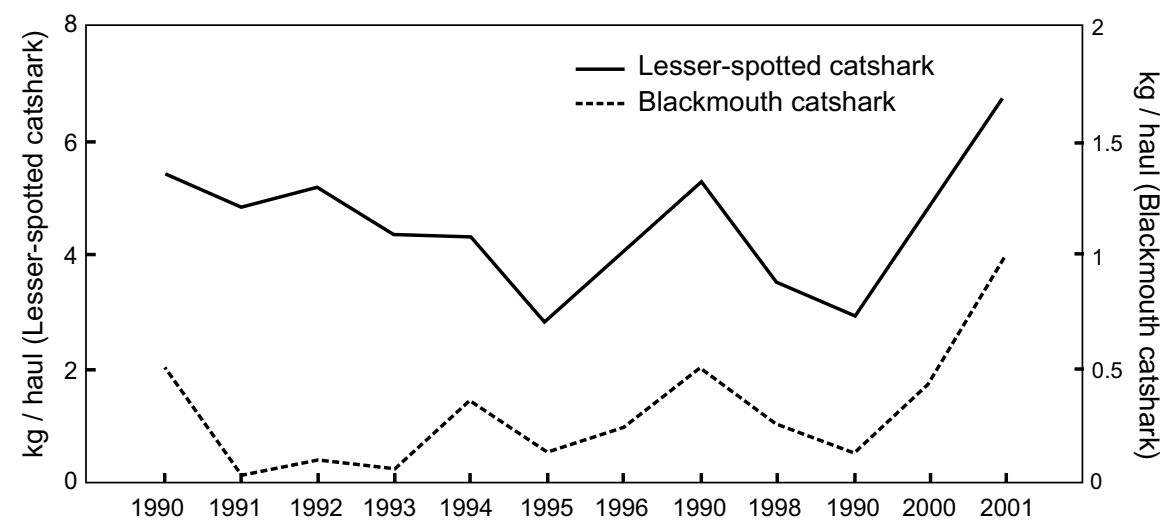

Fig. 3. Biomass indices ( $\mathrm{kg} / 30 \mathrm{~min}$ haul) of lesser-spotted catshark and blackmouth catshark in the Cantabrian Sea.

the entire length distribution. Horn's index of diet overlap was 0.76 between lesser-spotted catshark and blackmouth catshark, and the values of Horn's indices between the three length-classes of the two catshark species were high (Table 4). Overlap is considered biologically significant when the Horn index value exceeds 0.60 (Zaret and Rand, 1971; Mathur, 1977). There was a low overlap value when comparing lesser-spotted catshark $<30 \mathrm{~cm} \mathrm{TL}$ and blackmouth catshark $\geq 50 \mathrm{~cm} \mathrm{TL}$, and a value close to 0.60 (0.63) between lesser-spotted catshark $\geq 50 \mathrm{~cm}$ TL and blackmouth catshark $<30 \mathrm{~cm}$ TL. All other length-classes showed significant dietary overlap.

Variation in food volume: body weight by depth. More than half the diet of lesser-spotted catshark caught at depths $<120 \mathrm{~m}$ was decapods, and most of the remainder was fish (Fig. 6). Between 120 and $300 \mathrm{~m}$ depth, the amount of $M$. poutassou and euphausiids in its diet increased from $1.6 \% B W$ to $1.8 \% B W$. Beyond $300 \mathrm{~m}$, where the abundance of this species of catshark clearly diminished, the ratio of food consumption: body weight decreased to $1.5 \% \mathrm{BW}$ and decapods were less common, whereas the consumption of M. poutassou and cephalopods was higher (Fig. 6).

The ratio of food volume:body weight of blackmouth catshark at depths $<120 \mathrm{~m}$ was low $(1.3 \% B W)$; however, this ratio is based on only a few stomach contents samples available for analysis because this depth is near the limit of the distributional range of the species. At depths $\geq 120 \mathrm{~m}$, the ratio of food volume: body weight increased up to $2 \% B W$, with euphausiids and $M$. poutassou being important prey, and the consumption of decapods reduced. The ratio of food volume: body weight remained $\sim 2 \% B W$ beyond $300 \mathrm{~m}$, although the importance of euphausiids increased $(0.7 \% \mathrm{BW})$ and that of decapod crustaceans and M. poutassou decreased (Fig. 6). The ratio of food volume: body weight changed with the length of the catshark (Table $5)$ and was highest in the small catshark $(<30 \mathrm{~cm} \mathrm{TL})$.

Comparison of the diet of the two species of catshark sharing the same zones of coexistence. The percentage of empty stomachs varied little between the two species of catshark $<30 \mathrm{~cm}$ TL and $30-50 \mathrm{~cm}$ TL. However, empty stomachs were more common for lesser-spotted catshark $\geq 50 \mathrm{~cm}$ TL (20\%) than for large blackmouth catshark (9\%) (Table 6). The most important prey in the diet of both species of catshark $<30 \mathrm{~cm}$ TL were euphausiids, whereas endobenthic fauna, such as polychaetes, were only preyed on by lesser-spotted catshark. Euphausiids, brachiurans and anomurans were major prey of lesser-spotted catshark $30-50 \mathrm{~cm}$ TL, but only euphausiids were important prey for blackmouth catshark of the same length-class. The largest catshark preyed on M. potassou and other fishes. Several prey were of similar importance for lesser-spotted catshark, whereas fish, mainly M. potassou, were the main food of blackmouth catshark (Fig. 7).

Where lesser-spotted catshark and blackmouth catshark occurred together in the same area, Horn's index of diet overlap varied between 0.39 and 0.86 for different length-classes (Table 4). Values of Horn's indices were similar in the entire study area with the overlap index between lesser-spotted catshark $<30 \mathrm{~cm}$ TL and blackmouth catshark $\geq 50 \mathrm{~cm}$ TL being the only one smaller than 0.60 (Table 4).

\section{Discussion}

\section{Diets of lesser-spotted catshark and blackmouth catshark}

Previous studies have described feeding in catshark in the Atlantic Ocean and Mediterranean Sea (Mattson, 1981; 
Lesser-spotted catshark
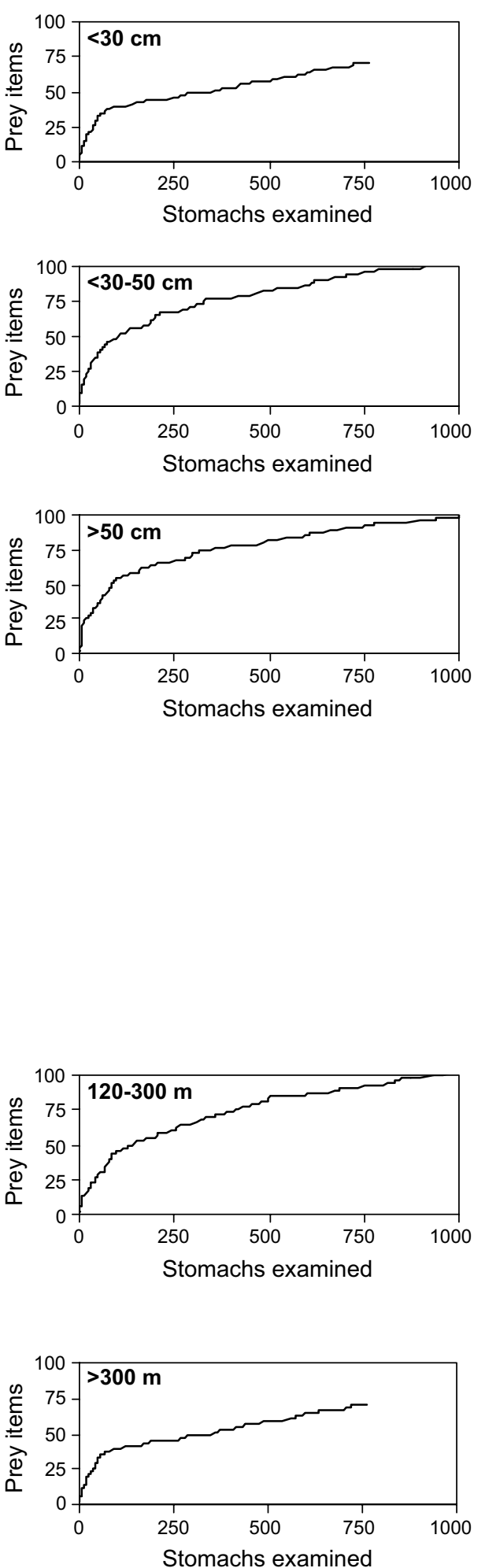

Blackmouth catshark
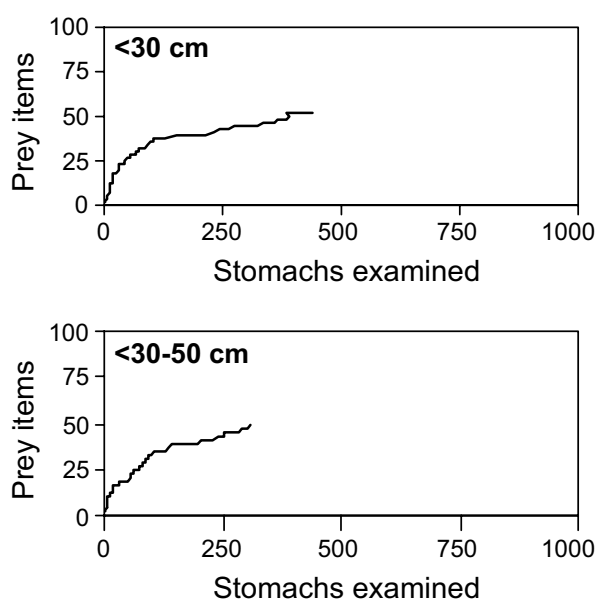

Stomachs examined
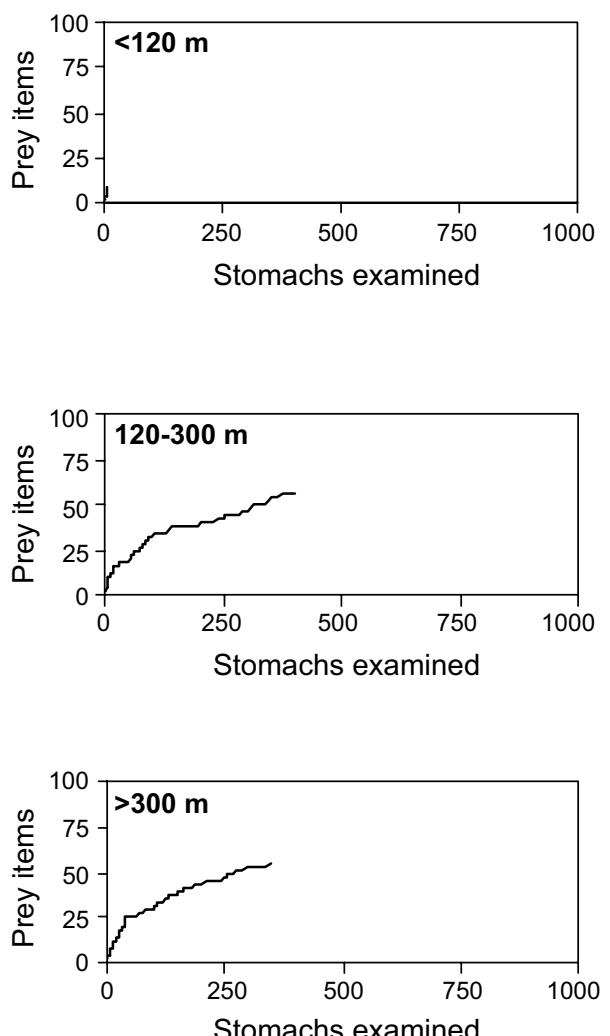

Fig. 4. Plots showing number of prey taxa vs number of stomachs analysed with food for each species, length-class and depth stratum. 
TABLE 1. Percentages of empty stomachs and stomachs from which food was regurgitated in different length-classes and depth strata for lesser-spotted catshark and blackmouth catshark.

\begin{tabular}{|c|c|c|c|c|c|c|}
\hline & \multicolumn{3}{|c|}{ Variable values for each length-class $(\mathrm{cm})$} & \multicolumn{3}{|c|}{ Variable value for each depth stratum (m) } \\
\hline & $<30$ & $30-49$ & $\geq 50$ & $<120$ & $120-299$ & $\geq 300$ \\
\hline \multicolumn{7}{|c|}{ Lesser-spotted catshark } \\
\hline$\%$ Empty & 11.46 & 12.85 & 16.60 & 14.04 & 14.28 & 8.97 \\
\hline$\%$ Regurgitated & 0.46 & 0.09 & 0.41 & 0.29 & 0.28 & 0 \\
\hline$\%$ Full & 88.08 & 87.07 & 82.99 & 85.67 & 85.44 & 91.03 \\
\hline Total number & 864 & 2242 & 1970 & 1026 & 3894 & 156 \\
\hline Mean length $(\mathrm{cm})$ & 24.09 & 39.35 & 56.23 & 48.09 & 41.75 & 50.69 \\
\hline \multicolumn{7}{|c|}{ Blackmouth catshark } \\
\hline \% Empty & 15.81 & 19.06 & 18.38 & 38.46 & 14.32 & 19.42 \\
\hline$\%$ Regurgitated & 0 & 0 & 0.74 & 0 & 0 & 0.21 \\
\hline$\%$ Full & 84.19 & 80.94 & 80.88 & 61.54 & 85.68 & 80.38 \\
\hline Total number & 525 & 299 & 136 & 13 & 468 & 479 \\
\hline Mean length $(\mathrm{cm})$ & 22.17 & 38.39 & 60.07 & 32.85 & 27.40 & 37.65 \\
\hline
\end{tabular}

Macpherson, 1981; Lyle, 1983; Carrassón et al., 1992), as well as in the Cantabrian Sea (Olaso and RodríguezMarín, 1995a; Velasco et al., 1996; Olaso et al., 1998; Gutiérrez-Zabala et al., 2001). In the present study, all the available data on the feeding of lesser-spotted catshark and blackmouth catshark during the autumn have been integrated to compare their food habits and the influence of their habitats on diet.

The variety of prey items found among the stomach contents of the two species indicates that they are broad generalists in their diets and habitat requirements. The diversity of taxa in the diet of the lesser-spotted catshark confirms that it is an opportunistic feeder irrespective of length-class, but especially so $\geq 30 \mathrm{~cm}$ TL (Lyle, 1983; Olaso et al., 1998). The diet of blackmouth catshark was less diverse than that of the lesser-spotted catshark. The blackmouth catshark is apparently less opportunistic and selects less varied prey than lesser-spotted catshark, which may result from the lower species richness of the fish and crustaceans living <300 m (Olaso, 1990; Sánchez, 1993). Mattson (1981) found blackmouth catshark in the Norwegian fjords fed on a peculiarly low variety of prey because it preys mostly on large prey, which are less abundant than small prey. Carrassón et al. (1992) found that at depths $<1000 \mathrm{~m}$, blackmouth catshark in all size-classes from Catalonian (Northwestern) Mediterranean had a more diverse diet than those in shallower water where their prey were more abundant.

High dietary overlap between lesser-spotted catshark and blackmouth catshark indicate the potential for resource competition. The diets of the two catshark species
$<30 \mathrm{~cm}$ TL were the most similar, and the diets diverged as they became larger. Thus, resource competition may be more intense between catsharks $<30 \mathrm{~cm}$ TL that live together in the same zones than between larger catsharks, partly because they occur in different habitats.

We found that the highest ratio of food volume to weight occurred for lesser-spotted catshark at depths $<300 \mathrm{~m}$, and for blackmouth catshark at greater depths. This may indicate optimal feeding rates for juveniles and adults of both species approximately coincide with the centre of the depth distribution their preferred habitat. However, changes in mean length with depth and subtle changes in the allometric relationship between stomach volume and body weight make these comparisons difficult. Previously, Sims and Davies (1994) indicated that young lesser-spotted catshark consume more food than adults in relation to their body size.

\section{Resources exploited by lesser-spotted catshark and blackmouth catshark}

During daytime, different suprabenthic organisms and demersal fish occur at particular depths (Mauchline and Gordon, 1984, 1991; Gordon et al., 1995; Gordon and Mauchline, 1996; Merrett and Haedrich, 1997). Although lesser-spotted catshark and blackmouth catshark display nocturnal activity (Pals et al., 1982; Carrassón et al., 1992; Bello, 1995), the behaviour of both species allows them to feed on prey from the benthic communities and from mid-water depths. However, the feeding habits of lesserspotted catshark are mostly benthic (Lyle, 1983; Olaso and Rodríguez-Marín, 1995a, 1995b) and blackmouth catshark are benthopelagic (Bozzano et al., 2001). In the Mediter- 
TABLE 2. Diet (\% volume) of lesser-spotted catshark and blackmouth catshark by length-class (cm).,+ lower than $0.1 \%$.

\begin{tabular}{|c|c|c|c|c|c|c|c|c|}
\hline \multirow[b]{2}{*}{ Prey Item } & \multicolumn{4}{|c|}{ Diet (\%volume) for lesser-spotted catshark } & \multicolumn{4}{|c|}{ Diet (\% volume) for blackmouth catshark } \\
\hline & $<30$ & $30-49$ & $\geq 50$ & Total & $<30$ & $30-49$ & $\geq 50$ & Total \\
\hline Crustacea & 68.6 & 48.9 & 35.2 & 42.3 & 64.5 & 47.8 & 25.7 & 39.1 \\
\hline Decapoda & 46.7 & 44.8 & 33.0 & 38.3 & 23.6 & 27.1 & 18.2 & 21.8 \\
\hline Munida spp. & 3.3 & 2.4 & 1.3 & 1.9 & + & + & + & + \\
\hline Pagurus prideaux & 5.7 & 8.0 & 7.1 & 7.4 & 0.1 & 4.3 & 0.5 & 1.6 \\
\hline Goneplax rhomboides & 1.1 & 0.8 & 0.4 & 0.6 & + & + & 0.2 & 0.1 \\
\hline Liocarcinus depurator & 2.0 & 3.0 & 2.2 & 2.5 & + & 0.1 & + & + \\
\hline Polybius henslowi & 3.6 & 8.0 & 5.3 & 6.3 & 0.1 & 2.1 & 0.6 & 0.9 \\
\hline Alpheus glaber & 3.6 & 4.3 & 2.2 & 3.1 & 1.4 & 0.4 & 0.6 & 0.7 \\
\hline Pasiphaea multidentata & + & + & + & + & 0.3 & 0.6 & 2.4 & 1.5 \\
\hline Pasiphaea sivado & + & + & + & + & 5.2 & 13.3 & 9.8 & 10.1 \\
\hline Processa sp. & 3.3 & 2.0 & 0.8 & 1.4 & 3.4 & 0.2 & + & 0.6 \\
\hline Sergestes robustus & + & + & + & + & + & + & 1.5 & 0.8 \\
\hline Solenocera membranacea & 2.7 & 1.8 & 1.4 & 1.6 & 0.9 & 0.6 & 0.2 & 0.4 \\
\hline Other Decapoda & 21.3 & 14.6 & 12.4 & 13.7 & 12.3 & 5.3 & 2.5 & 5.0 \\
\hline Euphausiacea & 14.5 & 1.8 & 1.1 & 2.1 & 36.1 & 14.1 & 5.5 & 13.4 \\
\hline Isopoda & 1.5 & 0.3 & 0.3 & 0.4 & 0.1 & 0.1 & 0.1 & 0.1 \\
\hline Mysidacea & 2.4 & 0.7 & 0.2 & 0.5 & 0.9 & 3.4 & 1.0 & 1.7 \\
\hline Other crustacea & 3.6 & 1.3 & 0.5 & 1.0 & 3.8 & 3.1 & 0.9 & 2.1 \\
\hline Mollusca & 3.9 & 4.2 & 7.6 & 6.1 & 4.1 & 0.8 & 2.7 & 2.4 \\
\hline Cephalopoda & 3.9 & 4.1 & 7.6 & 6.0 & 4.1 & 0.7 & 2.7 & 2.3 \\
\hline Other mollusca & + & 0.1 & + & 0.1 & + & 0.1 & + & 0.1 \\
\hline Polychaeta & 7.1 & 4.3 & 2.1 & 3.2 & 1.1 & 0.4 & + & 0.3 \\
\hline Other invertebrata & 2.1 & 2.8 & 1.7 & 2.1 & + & 1.3 & 3.2 & 2.2 \\
\hline Fish & 18.3 & 39.9 & 53.4 & 46.3 & 29.9 & 49.7 & 68.8 & 56.3 \\
\hline Gadiculus argenteus & 1.2 & 0.4 & 0.3 & 0.4 & 2.0 & 1.6 & + & 0.8 \\
\hline Micromesistius poutassou & 5.6 & 16.7 & 22.6 & 19.4 & 9.7 & 28.7 & 22.1 & 21.9 \\
\hline Merluccius merluccius & + & + & + & + & + & 2.6 & + & 0.8 \\
\hline Xenodermichthys copei & + & + & + & + & + & + & 2.0 & 1.1 \\
\hline Scomberesox saurus & + & + & + & + & + & 0.8 & 8.8 & 4.9 \\
\hline Argyropelecus spp. & + & + & + & + & + & + & 1.1 & 0.6 \\
\hline Mycthophid & + & + & + & + & 1.2 & 1.9 & 0.4 & 1.0 \\
\hline Trachurus trachurus & 0.4 & 0.6 & 2.1 & 1.4 & + & 1.9 & 9.3 & 5.4 \\
\hline Scomber scombrus & + & 0.9 & 2.2 & 1.6 & + & 0.1 & + & + \\
\hline Other fish & 11.1 & 20.5 & 23.0 & 21.4 & 17.0 & 12.3 & 25.2 & 19.8 \\
\hline Stomachs with food & 761 & 1952 & 1635 & 4348 & 442 & 242 & 110 & 794 \\
\hline Average length $(\mathrm{cm})$ & 24.09 & 39.35 & 56.23 & 43.3 & 22.17 & 38.39 & $6+7$ & 32.59 \\
\hline Number of phyla & 7 & 9 & 8 & 10 & 5 & 6 & 4 & 7 \\
\hline Number of taxa & 43 & 79 & 74 & 101 & 36 & 33 & 29 & 50 \\
\hline
\end{tabular}

ranean Sea, catshark eyes are of considerable importance for detecting their prey and their retinas adapt to the depth at which they occur (Bozzano et al., 2001). Lesser-spotted catshark adapt to the more variable light intensity in their coastal habitat and, except for euphausiids, their prey are not bioluminescent. In contrast blackmouth catshark have larger eyes and bioluminescent prey (Sergestes robustus, Pasiphaea sp.), mysids (Gnathophausia zoea), and fish (Argyropelecus sp., myctophids, Argentina sphyraena) are more important in their diet. The prey of blackmouth catshark in the Mediterranean Sea make extensive verti- cal migrations (Bello, 1995) and at least a fraction of the population ascends to the bottom of the near-surface mixed layer (Cartes et al., 1993; Bergstad et al., 1996). The adaptation of their eyes to depth is highly related to the distribution range of each species.

The catsharks change their habitat as they grow from juveniles to adults, with older lesser-spotted catshark moving closer to the shore and older blackmouth catshark moving further offshore. As catsharks grow the frequency of capture of euphausiids decreases and the capture of fish 


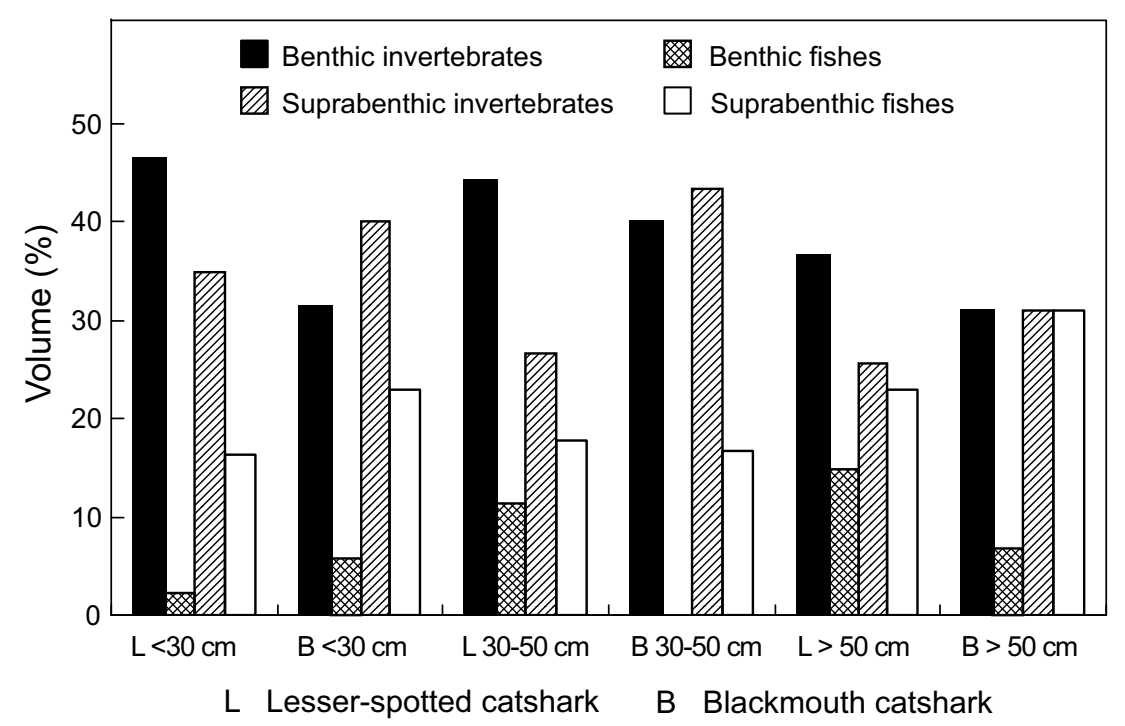

Fig. 5. Importance (\% volume) of prey types for different classes of lesser-spotted catshark (L) and blackmouth catshark (B).

TABLE 3. Number of taxa of the most important prey groups, and the taxonomic diversity and evenness of diets for different length-classes of lesser-spotted catshark and blackmouth catshark

\begin{tabular}{|c|c|c|c|c|c|c|c|c|}
\hline & \multicolumn{4}{|c|}{ Number of taxa for lesser-spotted catshark } & \multicolumn{4}{|c|}{ Number of taxa for blackmouth catshark } \\
\hline & $<30 \mathrm{~cm}$ & $30-49 \mathrm{~cm}$ & $\geq 50 \mathrm{~cm}$ & Total & $<30 \mathrm{~cm}$ & $30-49 \mathrm{~cm}$ & $\geq 50 \mathrm{~cm}$ & Total \\
\hline Anomura & 5 & 9 & 9 & 9 & 5 & 6 & 3 & 7 \\
\hline Brachyura & 6 & 9 & 6 & 9 & 3 & 3 & 3 & 4 \\
\hline Macrura & 2 & 4 & 3 & 4 & 2 & 1 & 1 & 2 \\
\hline Natantia & 7 & 13 & 11 & 13 & 10 & 9 & 7 & 12 \\
\hline Euphausiacea & 1 & 1 & 2 & 2 & 1 & 1 & 1 & 1 \\
\hline Mysidacea & 2 & 2 & 3 & 3 & 3 & 3 & 2 & 3 \\
\hline Ot crustacea & 5 & 6 & 6 & 6 & 6 & 4 & 4 & 6 \\
\hline Cephalopoda & 7 & 9 & 9 & 11 & 4 & 4 & 2 & 5 \\
\hline Other invertebrata & 8 & 13 & 11 & 16 & 2 & 3 & 2 & 4 \\
\hline Fish & 10 & 23 & 29 & 32 & 11 & 9 & 12 & 20 \\
\hline Taxa diversity (prey number) & 3.48 & 4.58 & 4.46 & 4.56 & 2.19 & 2.63 & 3.10 & 2.71 \\
\hline Evenness (prey number) & 0.61 & 0.73 & 0.73 & 0.69 & 0.39 & 0.48 & 0.60 & 0.45 \\
\hline Number of stomachs with food & 761 & 1952 & 1635 & 4348 & 442 & 242 & 110 & 794 \\
\hline Taxa diversity (prey volume) & 4.38 & 4.30 & 4.02 & 4.47 & 3.57 & 3.58 & 3.70 & 4.00 \\
\hline Evenness (prey volume) & 0.78 & 0.70 & 0.69 & 0.68 & 0.64 & 0.66 & 0.72 & 0.67 \\
\hline
\end{tabular}

increases, as has been described in other areas (Macpherson, 1980; Relini and Wurtz., 1975). The consumption of the mesopelagic fish $M$. poutassou is particularly important for both species, and so is the increase of the catch of cephalopods for lesser-spotted catshark. However, for this trophic change, another sensory organ, the olfactory lobes, is essential for these catsharks to detect and catch their prey. This organ has the ability to sense electrical impulses produced by an animal and it is larger in lesserspotted catshark. In addition to the sense of electroreception associated with the ampullae of Lorenzini and the sense of smell associated with the olfactory lobes, well developed fibres in the olfactory lobes of the lesser-spotted catshark might assist the species better locate its prey by electroolfaction. The detection of lifeless prey by lesserspotted catshark always starts with an olfactory alarm, and 
TABLE 4. Horn's index of dietary overlap for total volume of prey consumed by length-classes of lesser-spotted catshark and blackmouth catshark. Figures in upper section (bold) are for the whole study area, whereas figures in the lower section refer to the region in which both species were caught in the same trawls.

\begin{tabular}{|c|c|c|c|c|c|c|c|}
\hline & & \multicolumn{3}{|c|}{ Lesser-spotted catshark } & \multicolumn{3}{|c|}{ Blackmouth catshark } \\
\hline & & $<30 \mathrm{~cm}$ & $30-49 \mathrm{~cm}$ & $\geq 50 \mathrm{~cm}$ & $<30 \mathrm{~cm}$ & $30-49 \mathrm{~cm}$ & $\geq 50 \mathrm{~cm}$ \\
\hline \multirow[t]{3}{*}{ Lesser-spotted catshark } & $<30 \mathrm{~cm}$ & - & 0.87 & 0.76 & 0.81 & 0.79 & 0.57 \\
\hline & $30-50 \mathrm{~cm}$ & & - & 0.95 & 0.67 & 0.77 & 0.65 \\
\hline & $\geq 50 \mathrm{~cm}$ & & & - & 0.63 & 0.76 & 0.69 \\
\hline \multirow[t]{3}{*}{ Blackmouth catshark } & $<30 \mathrm{~cm}$ & 0.84 & 0.79 & 0.68 & \multirow[t]{3}{*}{-} & 0.83 & 0.65 \\
\hline & $30-50 \mathrm{~cm}$ & 0.76 & 0.86 & 0.82 & & - & 0.79 \\
\hline & $\geq 50 \mathrm{~cm}$ & 0.39 & 0.63 & 0.66 & & & - \\
\hline
\end{tabular}

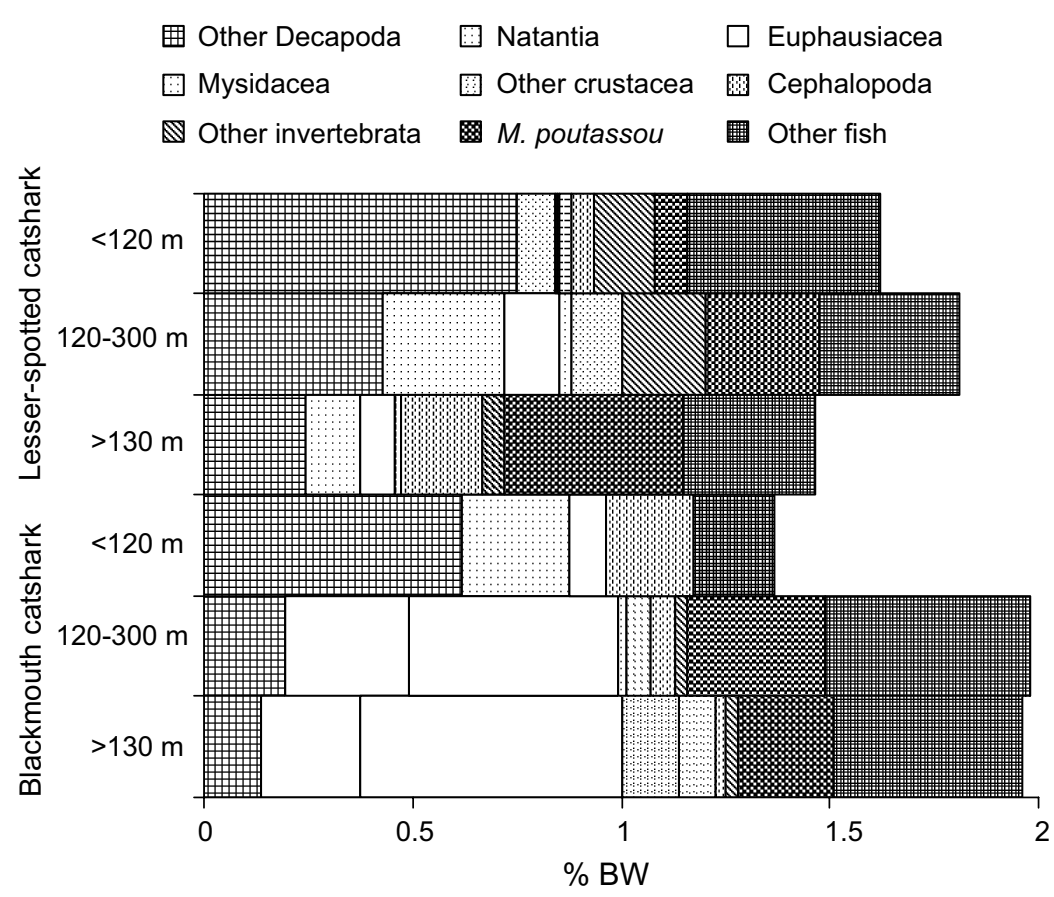

Fig. 6. Comparison of the \% prey volume/fish weight by depth strata, for lesserspotted catshark and blackmouth catshark.

TABLE 5. Variation in \% volume of food in stomach/total fish weight for different length-classes of lesser-spotted catshark and blackmouth catshark.

\begin{tabular}{lccc}
\hline \hline & \multicolumn{4}{c}{ Length range (cm) } \\
& $<30$ & $30-49$ & $\geq 50$ \\
\hline Lesser-spotted catshark & 3.07 & 1.96 & 1.05 \\
Blackmouth catshark & 2.54 & 1.69 & 1.17 \\
\hline
\end{tabular}


TABLE 6. Total number of stomachs and the percentage of empty stomachs for different length-classes of lesser-spotted catshark and blackmouth catshark that inhabit the same region.

\begin{tabular}{lrrr}
\hline \hline & \multicolumn{3}{c}{ Length-classes (cm) } \\
& $<30 \mathrm{~cm}$ & $30-49 \mathrm{~cm}$ & $\geq 50 \mathrm{~cm}$ \\
\hline Lesser-spotted catshark & 15.6 & 11.3 & 20.5 \\
\% Empty stomach & 96 & 97 & 166 \\
Total number of stomach contents & & & \\
Blackmouth catshark & 16.1 & 11.7 & 8.7 \\
\% Empty stomach & 211 & 111 & 23 \\
Total number of stomach contents & & & \\
\hline
\end{tabular}

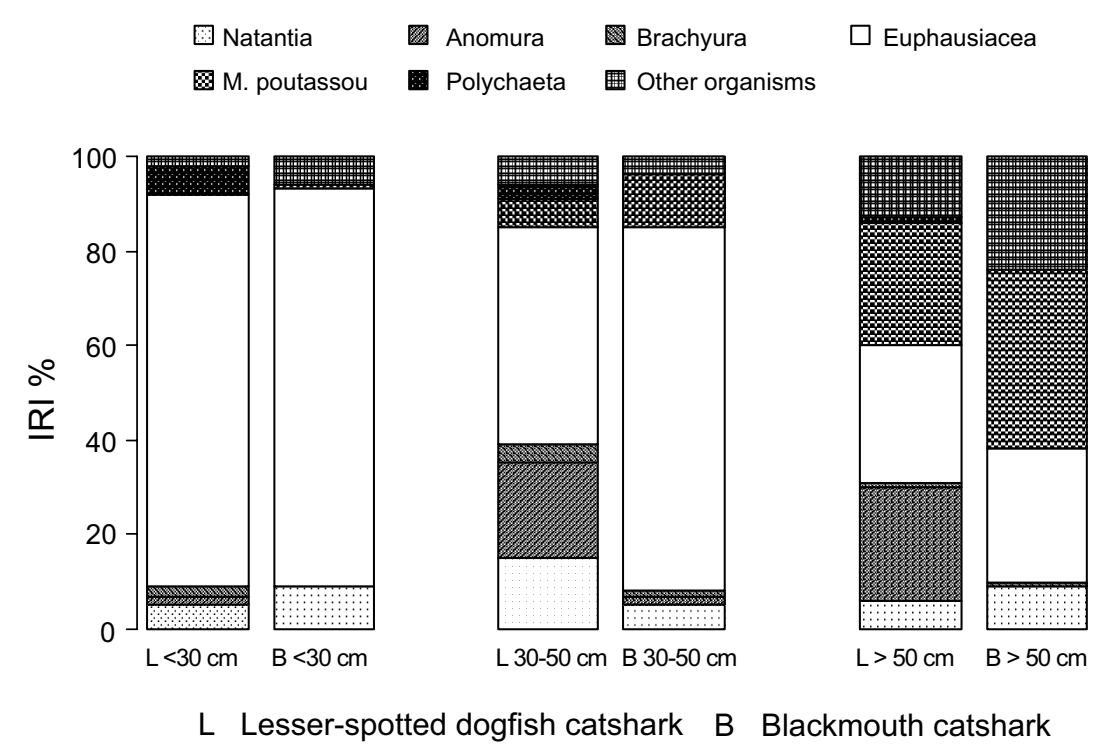

Fig. 7. Comparisons of the diets of lesser-spotted catshark and blackmouth catshark caught in the same hauls. Data expressed in IRI \%.

sharks use this organ to find prey and sense if the animal is dying (Dijkgraaf, 1975). The number of olfactory lamellae in the rosette increases with fish length (El-Attar, 1998). Also, visual acuity of catshark increases with age, and this allows them to detect larger prey at a greater distance (Bozzano et al., 2001). This combination of vision and smell makes it possible for lesser-spotted catshark to be scavengers and consumers of fishery discards (Kaiser and Spencer, 1994; Olaso et al., 1998 and 2002). In the diet of adult lesser-spotted catshark, many of the $M$. poutassou in the stomach contents are also discards, or consumed when dead or damaged (Olaso et al., 1998; Olaso et al., 2002). It is likely that large quantities of $M$. poutassou consumed by blackmouth catshark are also discards. This mid-water fish is the most important demersal species landed and discarded by the Spanish trawler fleet in the southern Bay of Biscay (Pérez et al., 1996).

Morphological characteristics of the eyes and olfactory lobes of both species probably result in differences in their search and capture of prey. The better sight and poorer smell of the blackmouth catshark favours the hunting and capture of prey that are found in the water column. The poorer sight and better smell of the lesser-spotted catshark suggests that this species is better adapted to consume benthic prey.

The life history characteristics of many sharks and rays make them very susceptible to overfishing (Graham et al., 2001; Baum et al., 2003). However, in the case of 
these catsharks, trawling in the Cantabrian Sea may have made them more abundant because fishing activity has supplemented their food with offal and discards. Previous studies have documented similar increases in abundance of catshark and small sharks that have accompanied the decline of commercial species (Fogarty and Murawsky, 1998; Rogers and Ellis, 2000). In most cases, the reasons for these increases are unknown. The increased abundance of lesser-spotted catshark probably results from scavenging on macrofauna, such as crustaceans and errant polychaetes (Serrano et al, 2003a, 2003b). These are taxa that benefit from disturbed sediments and organic matter generated by trawls and discards (Collie et al., 1997; Kaiser et al., 1998) including fish (Olaso et al., 1998). Changes in the abundance and diets of these two species of catshark may be good indicators of broadscale changes caused by increasing exploitation in their ecosystem.

\section{Acknowledgements}

We are very grateful to the Instituto Español de Oceanografía, particularly to José Gutiérrez-Zabala, for the opportunity of carrying out the historical series of food surveys. We also acknowledge the financial support of the European Commission for project DELASS, which made it possible to gather data for the present study.

\section{References}

BAUM, J. K., R. A. MYERS, D. G. KEHLER, B. WORM, S. J. HARLEY, and P. A. DOHERTY. 2003. Collapse and conservation of shark populations in the Northwest Atlantic. Science, 299(5605): 389-392.

BELLO, G., 1995. Cephalopods in the stomach contents of Galeus melastomus (Selachii, Scyliorhinidae) from the Adriatic Sea. Atti Soc. It. Sc. nat. Mus. civ. St. Nat., Milano, 134: $33-40$.

BERGSTAD, O. A., E. TORSTENSEN, and B. BØHLE. 1996. Micronekton and pelagic fishes in fjords on the Norwegian Skagerrak coast in winter. Fisken Hav., 5: 1-25.

BOZZANO, A., A. R. MURGIA, S. VALLERGA, J. HIRANO, and S. ARCHER. 2001. The photoreceptor system in the retinae of two dogfishes, Scyliorhinus canicula and Galeus melastomus: possible relationship with depth distribution and predatory lifestyle. J. Fish Biol., 59: 1258-1278.

CAPAPÉ, C., and J. ZAOUALI. 1976. Contribution à la biologie des Scyliorhinidae des côtes tunisiennes. V. Galeus melastomus (Rafinesque, 1810). Régime alimentaire. Arch. Inst. Pasteur Tunis, 53: 281-292.

1977. Contribution a la biologie des Scyliorhinidae des côtes tunisiennes VI: Galeus melastomus (Rafinesque, 1810) repartition géographique et bathymétrique, sexualité, reproduction. Cahiers Biologie Marine, Tome XVIII: 449-463.

CARRASSÓN, M., C. STEFANESCU, and J. E. CARTES,
1992. Diets and bathymetric distributions of two bathyal sharks of the Catalan deep sea (western Mediterranean). Mar. Ecol. Prog. Ser., 82: 21-30.

CARTES, J. E., F. SARDA, J. B. COMPANY, and J. LLEONART. 1993. Day-night migrations by deep-sea decapod crustaceans in experimental sampling in the western Mediterranean Sea. J. Exp. Mar. Biol. Ecol., 171: 63-73.

COCHRAN, W. 1971. Técnicas de muestreo. Cía. Ed. Continental, S.A. Mexico: 127-157.

COLLENOT, G. 1966. Observations relatives au développment au laboratoire d'embryons et d'individus juvéniles de Scyliorhinus canicula L. Cahiers de Biologie Marine, Tome VII, 319-330.

COLLIE, J. S., G. A. ESCANERO, and P. C. VALENTINE. 1997. Effects of bottom fishing on the benthic megafauna of Georges Bank. Marine Ecology Progress Series, 155: $159-172$.

COMPAGNO, L. J. V. 1984. FAO species catalogue. Sharks of the world. An annotated and illustrated catalogue of shark species known to date. FAO Fish. Sypn., No. 125, Vol. 4(2), 633 p.

DIJKGRAAF, S. 1975. The sensory physiology of prey perception in the dogfish Scyliorhinus canicula. Rev. Suisse Zool., 82(1): 41-46.

EL-ATTAR, A. E. 1998. Comparative morphological studies on the olfactory organs of two sharks, Squalus acanthias and Scoliodon walbeehmi in relation to their feeding habits. $J$. Union Arab Biol., Cairo, 9(A): 19-42.

ELLIS, J. R., and S. E. SHACKLEY. 1997. The reproductive biology of Scyliorhinus canicula in the Bristol channel, U.K. J. Fish Bio., 51: 361-372.

FOGARTY, M. J., and S. A. MURAWSKY. 1998. Largescale disturbance and the structure of marine systems: Fishery impacts on Georges Bank. Ecol. Appl., 8(1, suppl.): S6-S22

FORD, E., 1921. A contribution to our knowledge of the life histories of the dogfishes landed at Plymouth. J. Mar. Biol. Ass. U.K., 12: 468-505.

GORDON, J. D. M., N. R. MERRETT, and R. L. HAEDRICH. 1995. Environmental and biological aspects of slope-dwelling fishes of the North Atlantic Slope. In: Deep-water Fisheries of the North Atlantic Oceanic Slope. A. G. Hopper (ed.). Kluwer Academic Publishers, p. 1-26.

GORDON, J. D. M., and J. MAUCHLINE. 1996. The distribution and diet of the dominant, benthopelagic, slope-dwelling eel, Synaphobranchus kaupi, of the Rockall Trough. J. Mar. Biol. Assoc. U.K, 76: 493-503.

GRAHAM, K. J., N. L. ANDREW, and K. E. HODGSON. 2001. Changes in relative abundance of sharks and rays on Australian South East Fishery trawl grounds after twenty years of fishing. Mar. Freshwat. Res., 52(4): 549-561.

GUTIÉRREZ-ZABALA, J. L., F. VELASCO, and I. OLASO. 2001. Alimentación de veintiuna especies de peces demersales de la división VIIIc del CIEM. Otoños de 1994 y 1995. Inst. Esp. Oceanogr. Datos y Resúm., 16: 61 p.

HORN, H. S. 1966. Measurement of overlap in comparative ecological studies. Am. Nat., 100(914): 419-424.

HYSLOP, E. J. 1980. Stomach contents analysis: a review of 
methods and their application. J. Fish Biol., 17: 411-429.

KAISER, M. J., AND B. E. SPENCER. 1994. Fish scavenging behaviour in recently trawled areas. Mar. Ecol. Prog. Ser., 112(1-2): 41-49.

KAISER, M. J., D. B. EDWARDS, P. J. ARMSTRONG, K. RADFORD, N. E. L. LOUGH, R. P. FLATT, and H. D. JONES. 1998. Changes in megafaunal benthic communities in different habitats after trawling disturbance. ICES Jour. Mar. Sci., 55: 353-361.

LELOUP, J., and M. OLIVEREAU. 1951. Données biométriques comparatives sur la roussette (Scyllium canicula L.) de la Manche et de la Méditerranée. Vie Milieu., 2: 182-209.

LYLE, J. M. 1983. Food and feeding habits of the lesser spotted dogfish, Scyliorhinus canicula (L.), in Isle of Man waters. J. Fish Biol., 23(6): 725-737.

MACPHERSON, E. 1980. Régime alimentaire de Galeus melastomus Rafinesque, 1810, Etmopterus spinax (L., 1758) et Scymnorhinus licha (Bonnaterre, 1788) en Méditerranee occidentale. Vie Milieu, 30: 139-148.

1981. Resource partitioning in a Mediterranean demersal fish community. Mar. Ecol. Prog. Ser., 4: 183-193.

MATHUR, D. 1977. Food habits and competitive relationships on the bandfin shiner in Halawakee Creek, Alabama. Am. Midl. Nat., 97: 89-100.

MATTSON, S. 1981. The food of Galeus melastomus, Gadiculus argenteus thori, Trisopterus esmarkii, Rhinonemus cimbrius, and Glyptocephalus cynoglossus (Pices) caught during the day with shrimp trawl in a west Norwegian fjord. Sarsia, 66: 109-127.

MAUCHLINE, J., and J. D. M. GORDON. 1984. Diets of the sharks and chimaeroids of the Rockall Trough, northeastern Atlantic Ocean. Mar. Biol., 75: 269-278.

1991. Oceanic pelagic prey of benthopelagic fish in the benthic boundary layer of a marginal oceanic region. Mar. Ecol. Prog. Ser., 74: 109-115.

MERRETT, N. R., and R. L. HAEDRICH. 1997. Deep-Sea Demersal Fish and Fisheries. Chapman and Hall, London, $282 \mathrm{p}$.

OLASO, I. 1990. Distribución y abundancia del megabentos invertebrado en fondos de la plataforma Cantábrica. Publ. Espec. Inst. Esp. Oceanogr., n1 5: 128 p.

OLASO, I., and E. RODRÍGUEZ-MARÍN. 1995a. Alimentación de veinte especies de peces demersales pertenecientes a la División VIIIc del ICES. Otoño 1991. Inf. Téc. Inst. Esp. Oceanogr., 157: $56 \mathrm{p}$.

1995b. Decapod crustaceans in the diets of demersal fish in the Cantabrian Sea. ICES Mar. Sci. Symp., 199: 209-221.

OLASO, I., F. VELASCO, and N. PÉREZ. 1998. Importance of discarded blue whiting (Micromesistius poutassou) in the diet of lesser spotted dogfish (Scyliorhinus canicula) in the Cantabrian sea. ICES J. Mar. Sci., 55: 331-341.

OLASO, I., F. SÁNCHEZ, C. RODRÍGUEZ-CABELLO, and F. VELASCO. 2002. The feeding behaviour of some demersal fish species in response to artificial discard. Sci. Mar., 66(3): 301-331.

PALS, N., P. VALENTIJN, and D. VERWEY. 1982. Orientation reactions of the dogfish, Scyliorhinus canicula, to local electric fields. Netherlands Journal of Zoology,
32(4): 495-512.

PÉREZ, N., P. PEREDA, A. URIARTE, V. TRUJILlO, I. OLASO, and S. LENS. 1996. Descartes de la flota española en el área del ICES. Datos Resúm. Inst. Esp. Oceanogr., núm 2: $142 \mathrm{p}$.

PINKAS, L., M. S. OLIPHANT, and I. L. K. IVERSON. 1971. Food habits of albacore, bluefin tuna, and bonito in California waters. Calif. Dept. Fish and Game, Fish Bull., 152: $105 \mathrm{p}$.

PIELOU, E. C. 1966. The measurement of diversity in different type of biological collections. J. Theor. Biol., 13: $131-144$.

RELINI, L., and M. WURTZ. 1975. Remarks on feeding of Galeus melastomus from Ligurian bathyal grounds. Quad. Lab. Tecnol. Pesca, Ancona, 2(1): 17-36.

RODRÍGUEZ-CABELLO, C., F. VELASCO, and I. OLASO. 1998. Reproductive biology of lesser spotted dogfish Scyliorhinus canicula (L., 1758) in the Cantabrian Sea. Sci. Mar., 62(3): 187-191.

RODRÍGUEZ-CABELLO, C., A. FERNÁNDEZ, I. OLASO, and F. SÁNCHEZ. MS 2001. Survival of lesser spotted dogfish Scyliothinus canicula discarded by trawlers in the Cantabrian Sea. ICES C.M. Doc., No. 2001/N:06.

RODRIGUEZ-CABELLO, C., A. FERNÁNDEZ, I. OLASO, F. SÁNCHEZ, R. GANCEDO, A. PUNZÓN, and O. CENDRERO. 2004a. Overview of Continental Shelf Elasmobranch Fisheries in the Cantabrian Sea. J. Northw. Atl. Fish. Sci., 35: 375-385 (this volume).

RODRÍGUEZ-CABELLO, C., F. SÁNCHEZ, and F. VELASCO. 2004b. Growth of lesser spotted dogfish S. canicula (L., 1758) (L., 1758) in the Cantabrian Sea, based on tag-return data. J. Northw. Atl. Fish. Sci., 35: 131-140 (this volume).

ROGERS, S. I., and J. R. ELLIS. 2001. Changes in the demersal fish assemblages of British coastal waters during the 20th century. ICES J. Mar. Sci., 57(4): 866-881.

SÁNCHEZ, F. 1993. Las comunidades de peces de la plataforma del Cantabrico. Publ. Esp. Inst. Esp. Oceanogr., 13: $137 \mathrm{p}$.

SÁNCHEZ, F., M. BLANCO, and R. GANCEDO. 2002. Atlas de los peces demersales y de los invertebrados de interés comercial de Galicia y el Cantábrico. Otoño 1997-1999. CYAN, Proyectos y Producciones Editoriales (Edit.), 158 p., Madrid.

SÁNCHEZ, F., and A. SERRANO. 2003. Variability of groundfish communities of the Cantabrian Sea during the decade of the 1990s. ICES Mar. Scienc. Symp., 219: 219-260.

SERRANO, A., F. VELASCO, I. OLASO, and F. SÁNCHEZ. 2003a. Macrobenthic crustaceans in the diet of demersal fish in the Bay of Biscay in relation to abundance in the environment. Sarsia, 88: 36-48.

SERRANO, A., F. VELASCO, and I. OLASO. 2003b. Polychaete annelids in the diet of demersal fish from the southern shelf of the Bay of Biscay. J. Mar. Biol. Ass. U.K., 83: 619-623.

SHANNON, C. E., and W. WEAVER. 1949. The mathematical theory of communication. University of Illinois Press, Urbans.

SIMS, D. W., and S. J. DAVIES. 1994. Does specific dynamic action (SDA) regulate return of appetite in the lesser 
spotted dogfish, Scyliorhinus canicula. J. Fish Biol., 45(2): 341-348.

VELASCO, F., I. OLASO and F. DE LA GÁNDARA. 1996. Alimentación de veintidos especies de peces demersales de la división VIIIc del ICES. Otoños de 1992 y 1993. Inf. Téc. Inst. Esp. Oceanogr., 164: 62 p.

VELASCO, F., OLASO, I., and SÁNCHEZ, F. 2001. The role of cephalopods as forage for the demersal fish community in the southern Bay of Biscay. Fis. Res., 52(1-2): 65-77.

WALLACE, R. K. 1981. An assessment of Diet-Overlap Indexes. Am. Fish. Soc., 110: 72-76.

ZARET, T. M., and A. S. RAND. 1971. Competition in tropical stream fishes: support for the competition exclusion principle. Ecology, 52: 336-342. 